\title{
PENGEMBANGAN LKS BIOLOGI PADA SISWA KELAS X SMAN 1 BENGKULU BERDASARKAN HASIL STUDI PEMANFAATAN TANAMAN OBAT DI RT.08 SUKAMERINDU KOTA BENGKULU
}

\author{
Aprianti Suhidi $^{1 *}$, Kasrina ${ }^{1}$, Sri Irawati ${ }^{1}$ \\ ${ }^{1}$ Program Studi Pendidikan Biologi, Fakultas Keguruan dan Ilmu Pendidikan, Universitas Bengkulu \\ email: apriantisuhidi2013@gmail.com
}

\begin{abstract}
Abstrak
Penelitian ini bertujuan untuk mendeskripsikan keanekaragaman hayati tingkat spesies tanaman obat di Kelurahan Sukamerindu Kota Bengkulu, dan kelayakan LKS kelas X SMAN 1 Kota Bengkulu terhadap LKS hasil pengembangan pada pembelajaran. Metode penelitian yang digunakan adalah Borg and Gall. Penelitian tanaman obat ini dilakukan selama 2 bulan yaitu dari bulan April 2017 sampai Mei 2017 di Kelurahan Sukamerindu Bengkulu dan uji coba LKS dilakukan di kelas X SMAN 1 Kota Bengkulu. LKS Keanekaragaman hayati jenis tanaman obat dinyatakan sangat valid dan layak untuk diterapkan dalam pembelajaran. Organ dari tanaman obat yang bermanfaat sebagai obat bagi masyarakat Kelurahan Sukamerindu adalah daun, buah, akar, umni, rimpang, batang, bunga, getah, dan biji. Pemanfaatan yang paling banyak adalah daun dengan persentase pemakaian 40 jenis tanaman sebesar $43,8 \%$. Jenis tanaman di pekarangan yang bermanfaat sebagai obat bagi masyarakat Kelurahan sukamerindu diperoleh 54 jenis tanaman dari 33 famili yang paling banyak dimanfaatkan adalah Zingiberaceae.
\end{abstract}

Kata kunci : Lembar Kerja Siswa (LKS), Tanaman Obat, Keanekaragaman Hayati, Metode Borg and Gall.

\begin{abstract}
This study aims to describe the biodiversity level of medicinal plant species in Sukamerindu urban village of Bengkulu city, and the feasibility of LKS X SMAN 1 Kota Bengkulu towards LKS result of the learning. Motede research used is Borg and Gall. This research was conducted for 2 months, from April 2017 until May 2017 at Sukamerindu Bengkulu Village and LKS trial was conducted in X-class SMAN 1 Kota Bengkulu. LKS The biodiversity of medicinal plants is considered very valid and feasible to be applied in the learning process. Organs from medicinal plants that are useful as medicines for Sukamerindu Village are leaves, fruits, roots, umni, rhizomes, stems, flowers, sap, and seeds. The most widely used is the leaves with the percentage of use of 40 plant species of $43.8 \%$. Types of plants in the yard that is useful as a medicine for the community Sukamerindu village obtained 54 types of plants from 33 families are the most widely used is Zingiberaceae.
\end{abstract}

Keywords: Student Worksheet (LKS), Medicinal Plants, Biodiversity, Borg and Gall Method. 


\section{PENDAHULUAN}

Pendidikan adalah segala pengalaman belajar yang berlangsung dalam segala lingkungan dan sepanjang hidup. Lingkungan pendidikan berlangsung dalam segala lingkungan hidup, baik yang khusus diciptakan untuk kepentingan pendidikan maupun yang ada dengan sendirinya (Mudyahardjo, 1998). Bahan ajar adalah segala bentuk bahan yang digunakan untuk membantu guru/instruktur dalam melaksanakan kegiatan belajar mengajar (Setiawan, 2013). LKS yang disediakan oleh penerbit yang dipakai oleh peserta didik sudah mengacu kepada enam unsur utama dalam bahan ajar LKS menurut Damayanti (2013).

Tumbuhan Obat adalah tumbuhan yang dapat dipergunakan sebagai obat, baik yang di sengaja ditanam maupun tumbuh secara liar yang dapat ditemukan diberbagai belahan dunia, salah satunya di Negara Indonesia. Indonesia merupakan Negara yang memiliki kekayaan hayati yang cukup besar yang dapat dikembangkan, terutama untuk obat tradisional yang merupakan bahan atau ramuan, salah satunya adalah bahan tumbuhan (Wasito, 2011).

Sukamerindu merupakan salah satu kelurahan yang ada di Kota Bengkulu. Kelurahan Sukamerindu terletak di pusat Kota Bengkulu dan berdekatan dengan pesisir pantai. Berdasarkan data administrasi yang didapat dari profil Kelurahan Sukamerindu, diperoleh informasi bahwa Kelurahan Sukamerindu ini memiliki jumlah Kepala Keluarga (KK) sebanyak 1.499, dan terdapat $18 \mathrm{Rt}$ dari $9 \mathrm{Rw}$ yang ada di Kelurahan Sukamerindu. RT 08 merupakan salah satu RT di Kelurahan Sukamerindu yang berdasarkan observasi, diketahui bahwa masyarakat di RT 08 Kelurahan
Sukamerindu ini memanfaatkan pekarangan rumah untuk membudidayakan tanaman yang diperlukan untuk kebutuhan seharihari, termasuk tanaman yang dipercaya oleh masyarakat bermanfaat sebagai obat dalam mengobati suatu penyakit.

Berdasarkan hal tersebut, maka peneliti mengembangkan LKS berdasarkan studi tanaman obat di pekarangan rumah masyarakat RT 08 Kelurahan Sukamerindu Kota Bengkulu. Penelitian ini memberikan informasi kepada siswa SMA N 1 Kota Bengkulu tentang tanaman apa saja yang dapat digunakan sebagai obat, serta bagian organ tubuh tanaman mana yang dapat dimanfaaatkan dalam pengobatan penyakit tertentu. Selain itu, hasil penelitian ini akan memudahkan siswa dalam memahami konsep keanekaragaman hayati tigkat spesies dan manfaatnya dengan memanfaatkan sumber belajar yang berada di lingkungan sekitar mereka. 1. Berdasarkan latar belakang masalah yang telah diuraikan diatas, maka rumusan masalah dalam penelitian ini adalah sebagai berikut : Bagaimana desain pengembangan LKS biologi pada siswa kelas X SMA N 1 Bengkulu berdasarkan eksplorasi tanaman obat di RT.08 Sukamerindu Kota Bengkulu? 2. Bagian organ apa saja pada tanaman obat yang dimanfaatkan oleh masyarakat di RT.08 Sukamerindu serta bagaimana cara pengolahan dan penggunaanya? 3. Jenisjenis tumbuhan obat apa saja yang di manfaatkan oleh masyarakat di RT.08 Sukamerindu?. Tujuan Penelitian ini adalah : 1. Mengetahui desain pengembangan LKS biologi pada siswa kelas X SMA Negeri 1 Kota Bengkulu berdasarkan eksplorasi tanaman obat di RT.08 Sukamerindu Kota Bengkulu, 2. Mengetahui organ apa saja pada tanaman obat yang dimanfaatkan oleh masyarakat RT.08 Sukamerindu, 3. Mengetahui berbagai 
jenis tanaman obat yang dimanfaatkan oleh masyarakat RT.08 Sukamerindu.

\section{METODE}

Penelitian ini adalah penelitian dan pengembangan. Menurut Sugiyono (2016), model penelitian pengembangan dapat diartikan sebagai cara ilmiah untuk meneliti, merancang, memproduksi dan menguji validitas produk yang telah dihasilkan. Metode penelitian yang digunakan dalam penelitian ini, yaitu metode Borg and Gall yang dimodifikasi oleh Sugiyono.

Teknik Pengumpulan data pada penelitian ini yaitu observasi, angket, wawancara. Prosedur penelitian dilaksanakan dengan mengacu pada langkah-langkah penelitian Borg and Gall (1989) dalam Sugiyono (2011) yang telah dimodifikasi. Adapun langkah-langkahnya sebagai berikut : 1 . Potensi dan masalah, 2. Mengumpulkan informasi, 3. Desain produk, 4. Validasi Produk, 5. Perbaikan desain, 6. Uji coba produk.

Teknik analisis data yang digunakan pada penelitian ini yaitu: 1 . Teknik analisis data hasil observasi. 2. Teknik analisis data hasil wawancara, Data hasil wawancara dilakukan pada guru biologi dan siswa untuk memperoleh informasi mengenai LKS yang digunakan guru biologi akan dianalisis secara deskriptif. 3. Teknik Analisis Data Instrumen Angket Adapun pedoman perhitungan prosentase skor angket validasi dari ahli materi, media, guru biologi akan dirubah menjadi data kuanitatif. Skor yang didapat masing-masing anget dihitung menggunakan rumus dan disesuaikan dengan kategori penilian ideal sebagai berikut (Arikunto, 2013).

$$
\mathrm{P}=\frac{\sum x}{\sum x i} x 100 \%
$$

Keterangan:

$\mathrm{P} \quad=$ presentasi kevalidan

$\sum x i=$ jumlah nilai ideal per item

$\sum x=$ jumlah jawaban responden per item $100 \%=$ konstanta

Hasil analisis data yang berupa presentase tersebut kemudian dicocokan dengan kroteria kevalitan (tabel 1). Kemudian akan dijadikan dasar dilakukan layak atau tidak LKS tersebut diimplementasikan.

Tabel 1 1. Kriteria Validitas LKS

\begin{tabular}{|c|c|c|}
\hline Persentase\% & $\begin{array}{l}\text { Kriteria } \\
\text { Validitas }\end{array}$ & Keterangan \\
\hline $81,25-100$ & $\begin{array}{l}\text { Sangat } \\
\text { valid }\end{array}$ & $\begin{array}{l}\text { Layak/Tidak } \\
\text { revisi }\end{array}$ \\
\hline $62,50-81,24$ & Valid & $\begin{array}{l}\text { Cukup } \\
\text { layak/Tidak } \\
\text { revisi }\end{array}$ \\
\hline $43,75-62,49$ & $\begin{array}{l}\text { Kurang } \\
\text { valid }\end{array}$ & $\begin{array}{l}\text { Kurang } \\
\text { layak/ revisi } \\
\text { sebagian }\end{array}$ \\
\hline $25-43,74$ & $\begin{array}{l}\text { Sangat } \\
\text { kurang } \\
\text { valid }\end{array}$ & $\begin{array}{l}\text { Tidak } \\
\text { layak/revisi } \\
\text { total }\end{array}$ \\
\hline
\end{tabular}

HASIL DAN PEMBAHASAN

Berdasarkan penelitian mengenai pemanfaatan tanaman obat di Kelurahan Sukamerindu Kota Bengkulu, dari 36 responden diperoleh 33 famili yang terdiri dari atas 54 spesies tanaman yang bermanfaat sebagai obat untuk penyembuhan penyakit.

Untuk mengobati penyakit, masyarakat Kelurahan Sukamerindu memanfaat bagian tanaman tertentu dari suatu tanaman yang dipercaya memiliki daya kerja dalam penyembuhan penyakit. Bagian-bagian dari tanaman di pekarangan 
yang dimanfaatkan sebagai obat oleh masyarakat Kelurahan Sukamerindu adalah berupa akar, batang, daun, bunga, buah, biji, getah, umbi dan rimpang. Dibawah ini, merupakan bagian tanaman yang digunakan untuk mengobati penyakit dengan jumlah tanaman yang dimanfaatkan bagian organnya.

Tabel 4.1 Jumlah tanaman dengan bagian organ yang dimanfaatkan

\begin{tabular}{ccc}
\hline No. & Bagian yang digunakan & $\begin{array}{c}\text { Jumlah } \\
\text { tanaman }\end{array}$ \\
\hline $\mathbf{1 .}$ & Daun & 40 \\
$\mathbf{2}$. & Buah & 18 \\
$\mathbf{3 .}$ & Akar & 9 \\
$\mathbf{4 .}$ & Umbi & 1 \\
$\mathbf{5 .}$ & Rimpang & 4 \\
$\mathbf{6 .}$ & Batang & 6 \\
$\mathbf{7 .}$ & Bunga & 5 \\
$\mathbf{8 .}$ & Biji & 6 \\
$\mathbf{9 .}$ & Getah & 1 \\
\hline
\end{tabular}

Berdasarkan Tabel 4.1 terdapat keberagaman dalam jumlah dari bagian tanaman yang digunakan sebagai obat dari 54 jenis tanaman di pekarangan yang ditemukan dan bermanfaat sebagai obat bagi masyarakat. Berikut merupakan persentase dari jumlah tanaman dengan bagian yang dimanfaatkan.

Bagian tanaman yang paling banyak digunakan dalam pengobatan adalah daun, dan bagian tanaman yang paling sedikit digunakan adalah umbi dan getah. Sebanyak 40 jenis tanaman (43,8\%) dimanfaatkan daunnya untuk pengobatan, bagian buah sebanyak 18 jenis tanaman
(20.2\%), bagian akar sebanyak 9 jenis tanaman (10.1\%), bagian rimpang sebanyak 4 jenis tanaman (4.4), bagian batang dan biji sebanyak 6 jenis tanaman (6.7\%), bagian bunga sebanyak 5 jenis tanaman (5.6\%), bagian umbi dan getah hanya terdapat 1 jenis tanaman (1.1\%).

Berdasarkan hasil penelitian yang dilakukan jenis-jenis tanaman obat dengan habitus herba adalah : Andrographis paniculata (Sambiloto), Amaranthus spinosus (Bayam duri), Apium graveolens (Seledri), Impatient balsamina (Inai pacar), )), Cucumis sativus (Timun suri), Ocimum basilicum (Selasih), Ocimum tenuiflorum (Ruku-ruku),Ocimum sanctum (Kemangi), Orthosipon spicatus (Kumis kucing), Allium fistulosum (Bawang daun), Allium odorum (Kucai), Aloe vera (Lidah buaya), Mirabilis jalapa (Bunga pukul empat), Pandanus amaryllifolius (Pandan wangi), Cymbopogon citratus (Serai), Alpinia galangal (Laos), Curcuma aeruginosa (Kunyit hitam), Curcuma longa (Kunyit), Kaemferia galanga (Kencur), Zingiber officinale (Jahe), Zingiber purpureum (Jerangau).

Jenis-jenis tanaman dengan habitus perdu adalah :Graptophyllum pictum (Puding merah), Cananga odorata (Kenanga), Carica papaya (Pepaya), Muntinga calabura (Kersen), Jatropha curcas (Jarak pagar), Jatropha podagrica (Jarak hias), Manihot utilisima (Ubi kayu), Sauropus androgynus (Katuk), Leucaena leucocephala (Petai cina), Cordyline terminalis (Andong), Hibiscus rosasinensis (Kembang sepatu), Citrus microcarpa (Jeruk Kalamansi), Citrus hystrix (Jeruk Purut), Citrus aurantifolia (Jeruk nipis), Dracaena augustifolia (Daun Suji), Morinda citrifoli (Mengkudu), Solanum torvum (Rimbang). 
Jenis-jenis tanaman dengan habitus pohon adalah: Spondias pinnata (Kedondong), Annona muricata (Sirsak), Annona squamosa (Srikaya), Cocos nucifera (Kelapa hijau), Gnetum gnemon (Melinjo), Parsea Americana (alpukat), Artocarpus integra (Nangka), Moringa oleifera (Kelor), Psidium guajava (Jambu biji). Averhoa bilimbi (Belimbing wuluh), Averrhoa carambola (Belimbing manis), Naphelium lappaceum (Rambutan). Jenis-jenis tanaman dengan habitus semak adalah: Catharanthus raseus (Tapak dara), Piper betle (Sirih), Piper crocatum (Sirih merah), Rosa hybrida (Mawar)

\section{PENUTUP}

\section{Simpulan}

1. LKS biologi SMA kelas $X$ dengan konsep Keanekaragaman jenis tanaman obat dapat menuntun siswa kelas X IPS 4 SMA N 1 Kota Bengkulu dalam belajar dan menemukan konsep. LKS Keanekaragaman hayati jenis tanaman obat dinyatakan sangat valid dan layak untuk diterapkan dalam pembelajaran

2. Organ dari tanaman obat yang bermanfaat sebagai obat bagi masyarakat Kelurahan Sukamerindu adalah daun, buah, akar, umni, rimpang, batang, bunga, getah, dan biji. Pemanfaatan yang paling banyak adalah daun dengan persentase pemakaian 40 jenis tanaman sebesar $43,8 \%$

3. Jenis tanaman di pekarangan yang bermanfaat sebagai obat bagi masyarakat Kelurahan sukamerindu diperoleh 54 jenis tanaman dari 33 famili yang paling banyak dimanfaatkan adalah Zingiberaceae.

\section{Saran}

1. Perlu dilakukan penelitian lebih lanjut mengeani kandungan senyawa kimia pada tanaman yang dimanfaatkan sebagai obat yang ditemukan pada saat penelitian.

2. produk ini dapat digunakan untuk uji coba lapangan pada skla yang lebih luas dengan melibatkan sampel sekolah dan jumlah siswa yang lebih banyak serta heterogen

\section{DAFTAR PUSTAKA}

Borg, W.R dan Gall, M.D. 1983. Educational Research An Intro duction. New York: Longman

Damayanti, Dyah Shinta. 2013. Pengembangan Lembar Kerja Siswa (LKS) Dengan Pendekatan Inkuiri Terbimbing Untuk Mengoptimalkan Kemampuan Berfikir Kritis Peserta Didik Pada Materi Listrik Dinamis SMA Negeri 3 Purworejo Kelas $X$ Tahun Pelajaran 2012/2013. Jurnal radiasi volJurnal Radiasi Vol. 3 No. 1. (http://ejournal.umpwr.ac.id/index.p $\mathrm{hp} /$ radiasi/article/view/658.diakses18 januari 2016).

Mudyahardjo, Redja. 2013. Pengantar Pendidikan. Jakarta : PT Rajagrafindo

Setiawan, Andi. 2013. Artikel Penerapan Buku Saku Mastercam untuk Meningkatkan Keaktifan dan Kompetensi Siswa pada Mata Pelajaran CNC di SMKN 2 Depok Slamen. Yogyakarta : Program Studi Pendidikan Teknik Mesin Fakultas Teknik Universitas Negeri Yogyakarta. 
Sugiyono. 2011. Metode Penelitian Kuantitatif Kualitatif dan $R$ \& $D$. Bandung: Alfabeta

Sugiyono. 2016. Metode Penelitian Kuantitatif Kualitatif dan $R \quad \& \quad D$. Bandung: Alfabeta
Suriawiria, U. 2000. Obat Mujarab dari Perkarangan Rumah. Jakarta : Papas Sinar Sinanti

Wasito, Hendri. 2011. Obat Tradisional Kekayaan Indonesia. Yogyakarta : Graha IImu 